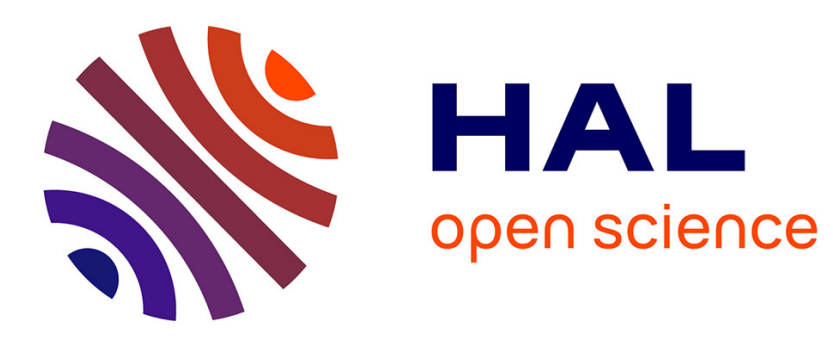

\title{
Provisioning rules and bank lending: A theoretical model
}

\author{
Vincent Bouvatier, Laetitia Lepetit
}

\section{To cite this version:}

Vincent Bouvatier, Laetitia Lepetit. Provisioning rules and bank lending: A theoretical model. Journal of Financial Stability, 2012, 8, pp.25 - 31. 10.1016/j.jfs.2011.04.001 hal-01098957

\section{HAL Id: hal-01098957 \\ https://hal.science/hal-01098957}

Submitted on 30 Dec 2014

HAL is a multi-disciplinary open access archive for the deposit and dissemination of scientific research documents, whether they are published or not. The documents may come from teaching and research institutions in France or abroad, or from public or private research centers.
L'archive ouverte pluridisciplinaire HAL, est destinée au dépôt et à la diffusion de documents scientifiques de niveau recherche, publiés ou non, émanant des établissements d'enseignement et de recherche français ou étrangers, des laboratoires publics ou privés. 


\title{
Provisioning Rules and Bank Lending:
}

\section{A Theoretical Model ${ }^{*}$}

\author{
Vincent Bouvatier ${ }^{\dagger} \quad$ Laetitia Lepetit ${ }^{\ddagger}$
}

\begin{abstract}
This paper develops a partial equilibrium model of a banking firm to analyze how provisioning rules influence loan market fluctuations. We show that a backwardlooking provisioning system amplifies the pro-cyclicality of loan market fluctuations. We demonstrate that, in a forward-looking provisioning system where statistical provisions are used to smooth the evolution of total loan loss provisions, the issue of pro-cyclicality of loan market fluctuations does not exist. Our results support the recent call of the Basel Committee for the implementation of a forward-looking provisioning system to address procyclicality.
\end{abstract}

JEL classification: G21

Keywords: loan market, provisioning system, pro-cyclicality

*We would like to thank Carlos Bautista, Christian Bordes, Thérèse Chevallier-Farat, Falko Fetch, Antoine Faure-Grimaud, Andy Mullineux, Emmanuelle Nys, Alain Sauviat, Frank Strobel, Amine Tarazi, Clas Wihlborg and anonymous referees for their helpful comments. The usual disclaimer applies.

†Université de Paris Ouest - Nanterre La Défense, EconomiX - CNRS, 200 Avenue de la République, 92001 Nanterre, France. E-mail: vbouvatier@u-paris10.fr

‡Université de Limoges, LAPE, 5 rue Félix Eboué, 87031 Limoges Cedex, France. E-mail: laetitia.lepetit@unilim.fr 


\section{Introduction}

An excessive cyclicality of bank lending can create a number of potential problems such as exacerbating the business cycle, increasing systemic risk and misallocating lending resources (Berger and Udell, 2004). As a result, all factors which amplify the cyclicality of bank lending may represent risks to both the macroeconomy and financial stability. Several theories of bank behavior, such as disaster myopia (Guttentag and Herring, 1986), herd behavior (Rajan, 1994) or the institutional memory hypothesis (Berger and Udell, 2004), highlight the role of banks in the pro-cyclical variations in loan market conditions. Empirical investigations (Asea and Blomberg, 1998; Lown and Morgan, 2006) also show that changes in lending standards imposed by banks increase the cyclicality of bank lending and then amplify the business cycle. Some authors also show that the capital adequacy constraint may lead banks behavior to amplify the credit cycle (Bikker, 2004, Zicchino, 2005) ${ }^{1}$.

However, the literature mentioned above provides only a partial explanation of the stylized facts about cyclicality because it disregards banks' provisioning practices and their links with the cyclicality of bank lending. In this paper, we focus on provisioning rules and their effects on the loan market. In most countries, loan loss provisions are made up of general provisions and specific provisions. General provisions refer to probabilistic losses that cannot be supported by loan specific documentation. There are therefore highly judgmental and are in many countries subject of regulatory restrictions. Specific provisions refer instead to certain events (such as due payments or other defaultlike events) for which a specific documentation can be produced and they are tied by

\footnotetext{
${ }^{1}$ Capital requirements is said to be procyclical because during a downturn capital becomes more expensive and banks often respond by cutting bank lending or shifting towards lower-risk customers. By contrast, in the boom phase, banks can obtain additional capital under more favorable terms, which may give further impetus to their lending.
} 
accounting rules to identified problem loans. Such provisioning systems are therefore said to be backward-looking. Specific provisions are mainly linked to problem loans and are therefore counter-cyclical ${ }^{2}$. Stylized facts show that total loan loss provisions are negatively affected by the output growth rate (Cavallo and Majnoni, 2001; Laeven and Majnoni, 2003; Bikker and Metzemakers, 2005) and that the ratio of loan loss provisions to total loans is highly counter-cyclical (Clerc et al., 2001; Arpa et al., 2001; Fernandez de Lis et al., 2001; Pain, 2003). This suggests that specific provisions are the main determinant of changes in total loan loss provisions ${ }^{3}$.

We consider that such a backward-looking provisioning system represents an unsatisfactory institutional arrangement over a business cycle because expected loan losses are inadequately taken into account, being mainly covered with specific provisions when loans turn bad. On the contrary, banks should rather cover their expected loan losses progressively as soon as loans are granted. The gap between loan loss provisions and expected loan losses could affect loan market fluctuations, given that loan loss provisions directly affect the cost of bank lending. If banks do not build up loan loss provisions during economic upswings, the cost of loans is understated. Banks have then incentives to ease lending standards. By contrast, during a downturn, the cost of loans is understated if banks had not accumulated loan loss reserves over prior periods to deal with contemporaneous problem loans. Banks can therefore tighten conditions on the loan market.

A forward-looking provisioning system, also called a dynamic or statistical provision-

\footnotetext{
${ }^{2}$ Indeed, specific provisions increase during an economic downturn when a significant deterioration in credit quality occurs, and decrease during an economic upswing when the likelihood of loan default is low.

${ }^{3}$ Banks can also develop a discretionary income smoothing behavior (Cavallo and Majnoni, 2001; Laeven and Majnoni, 2003; Bikker and Metzemakers, 2005). When earnings are expected to be low (high), loan loss provisions are deliberately understated (overstated) to mitigate adverse effects of other factors on earnings. Such a behavior can reduce the cyclicality of loan loss provisions.
} 
ing system ${ }^{4}$, could provide a satisfactory institutional arrangement to cover expected loan losses. In such a system, a new element, called the statistical provisions, is introduced aside from specific and general provisions. These statistical provisions are defined by accounting rules to cover expected losses. Banks have to evaluate the latent risk over a whole business cycle of their loan portfolio. Statistical provisions are defined as the difference between the estimation of latent losses and specific provisions. During an upswing phase, specific provisions are generally low and banks can therefore build up a fund of statistical provisions. Conversely, during a downturn, specific provisions increase and can be greater than latent losses, which means that the fund of statistical provisions previously accumulated is used to cope with numerous contemporaneous problem loans. As a result, statistical provisions offset the counter-cyclical evolutions of specific provisions, and total loan loss provisions are smoothed over time ${ }^{5}$.

The cyclicality of provisioning systems has already been investigated from an empirical point of view (Borio et al. 2001; Clerc et al., 2001; Bikker and Metzemakers, 2005 for example), as well as the impact of such cyclicality on bank lending (Bouvatier and Lepetit, 2008 and 2010). However, there is no theoretical model, to our knowledge, which examines the effects of loan loss provisions on the loan market. This paper is an attempt to fill this gap in the literature. More precisely, we develop a partial equilibrium model of a banking firm to analyze how provisioning rules influence loan market fluctuations. We show that a backward-looking provisioning system amplifies the pro-cyclicality of loan market fluctuations. We demonstrate that, in a forward-looking provisioning system

\footnotetext{
${ }^{4}$ See Fernandez de Lis et al. (2001), Mann and Michael (2002) and Jiménez and Saurina (2006) for more details about the forward-looking provisioning system. Such a system has been implemented in Spain since 2000 .

${ }^{5}$ Therefore, statistical provisions are an alternative to discretionary loan loss provisions made for income smoothing. Indeed, Pérez et al. (2008) show that the implementation of a dynamic provisioning system in Spain reduced the income smoothing behavior.
} 
where statistical provisions are used to smooth the evolution of total loan loss provisions, the issue of pro-cyclicality of loan market fluctuations does not exist. Our results support the recent call of the Basel Committee for the implementation of a forward-looking provisioning system to address procyclicality (Basel Committee on Banking Supervision, 2010).

The remainder of the paper is organized as follows. Section 2 presents the theoretical model. The optimal behavior of the bank under the different provisioning systems is presented in section 3. Section 4 concludes the paper.

\section{The model}

We develop a partial equilibrium model of a representative banking firm. We assume that the representative bank $i(i=1, \ldots, N)$ is specialized in loans of type $i$. Specialization can refer to a type of borrower, sector or to a geographical area (Carletti et al., 2007). The representative bank $i$ supply therefore only loans of type $i$ and operates in a monopolistic competition market. We also assume that the bank $i$ faces an exogenous business cycle.

Our aim is to explicitly introduce bank provisioning behavior. Three provisioning systems are considered. Firstly, we consider a strict backward-looking provisioning system in which loan loss provisions are triggered by past due payments. In such a system, the bank evaluates its credit risk exposure over the short run (i.e. on current non performing loans) and then sets loan rates depending on economic conditions. Secondly, we examine a forward-looking provisioning system in which loan loss provisions consist of two components: one related to past due payments and another one related to expected losses in order to offset the counter-cyclical behavior of the first component. In this case, credit risk exposure is assessed over a whole business cycle. This implies that the determination 
of loan rates is less affected by economic conditions. Finally, we consider the capital buffer system where the representative bank applies backward-looking provisioning rules and uses a capital buffer in order to cover expected losses which are not covered by loan loss provisions. The model allows comparison of the bank's behavior on the loan market in these three provisioning systems ${ }^{6}$. As the loan rate depends on the provisioning rules, the Modigliani-Miller theorem breaks down and then the choice of accounting methods matters for real decisions.

\subsection{Activities of the bank and profit function}

The representative bank $i$ performs an intermediation activity ${ }^{7}$. We assume that banks supply long-term loans with a flexible interest rate $^{8}$. Its asset side is made up of loans $\left(L_{i, t}\right)$ and a safe assets $\left(S_{i, t}\right)$. As the loan portfolio contains expected loan losses, loan loss reserves $\left(L L R_{i, t}\right)$ are deducted from assets. Loans minus loan loss reserves are called net loans (Walter, 1991). The liability side is made up of $\operatorname{debts}^{9}\left(D_{i, t}\right)$ and equity $\left(K_{i, t}\right)$. The bank balance sheet identity is

$$
L_{i, t}-L L R_{i, t}+S_{i, t}=D_{i, t}+K_{i, t}
$$

\footnotetext{
${ }^{6}$ We do not include general provisions in our model, as they do not matter to modelize the countercyclicality of loan loss provisions (Clerc et al., 2001; Arpa et al., 2001; Fernandez de Lis et al., 2001; Pain, 2003).

${ }^{7}$ The model is written at time $t$.

${ }^{8}$ We assume a flexible interest rate on loans for computational simplicity.

${ }^{9}$ As in Van den Heuvel (2002), bank's liabilities include deposits as well as market debt. Moreover, we assume that all debt liabilities are covered by deposit insurance and that the deposit insurance premium is equal to zero. Therefore, the banks' debt-funding costs do not depend on the debt equity ratio and probability of bankruptcy. The explicit introduction of a positive deposit insurance premium would not alter any result relative to the bank provisioning behavior.
} 
We assume that equity and loan loss reserves are invested in safe assets such as government bonds ${ }^{10}$, so that

$$
S_{i, t}=L L R_{i, t}+K_{i, t}
$$

The safe asset is supposed to be a short term investment of one period. This assumption assures that equity and loan loss reserves are liquid and available to face losses.

The profit of bank $i\left(\Pi_{i, t}\right)$ comes from its intermediation activity

$$
\Pi_{i, t}=r_{i, t}^{L} L_{i, t}\left(1-\mathrm{J}\left(y_{t}\right)-\mathrm{G}\left(y_{t}\right)\right)+r_{t}^{M} S_{i, t}-r_{t}^{M} D_{i, t}-L L P_{i, t}-\delta L_{i, t} \mathrm{G}\left(y_{t}\right),
$$

where $r_{i, t}^{L}$ is the interest rate on loans, $r_{t}^{M}$ is the risk-free interest rate applied to debts and safe assets, $y_{t}$ is output, functions $\mathrm{J}\left(y_{t}\right)$ and $\mathrm{G}\left(y_{t}\right)$ represent respectively the fraction of non performing loans (i.e. problem loans) and the fraction of charged-off loans ${ }^{11}, L L P_{i, t}$ represents loan loss provisions and $\delta L_{i, t} \mathrm{G}\left(y_{t}\right)$ represents unanticipated charge-offs (i.e. charge-offs for which the bank did not set aside loan loss reserves $)^{12}$. The fractions of

\footnotetext{
${ }^{10}$ Not all government bonds can be considered as safe assets, particularly with the sovereign debt crisis undergone by some countries. But we consider that bonds underwriten by some countries such as Germany and the United-States can be considered as safer. However, the German euro denominated bonds can no longer be regarded as totally riskless given their exposure to the sovereign debt crisis of some European countries. The US dollar denominated bonds of the United-States are also not totally riskless due to the credit risk of the municipalities and the importance of national debt which exceeds $80 \%$ of GDP (Reinhart and Rogoff, 2009). Further, non-inflation indexed bonds face inflation risks, and countries whose exchange rates are not pegged to the euro or the USD will also face exchange rate risks if they hold reserves in German or US bonds.

${ }^{11}$ Charged-off loans occur when debts are uncollectible and are removed from the balance sheet.

${ }^{12}$ The loan portfolio is made up of three loan categories during period $t$ : (i) good loans, (ii) problem loans and (iii) charged-off loans. As we will see during the calibration of the model based mainly on the database Bankscope Fitch IBCA, most loans are good loans. Loans judged likely to produce a loss are classified as problem loans. Recognized losses are classified as charged-off loans. Most of these charged-off loans were classified as problem loans over prior periods. But some loans can directly move from category $(i)$ to category $(i i i)$. If the bank did not make loan loss reserves on them, they are called unanticipated charge-offs. We assume for simplicity that $\delta$ is constant. We could consider that this parameter is affected by a shock when numerous or few loans are directly move from category $(i)$ to category (iii) but this point is out of the scope of the paper.
} 
non performing loans and of charged-off loans are defined by

$$
\begin{aligned}
\mathrm{J}\left(y_{t}\right) & =j_{0}\left(y_{t} / y\right)^{-\omega} z_{t}, \\
\mathrm{G}\left(y_{t}\right) & =g_{0}\left(y_{t} / y\right)^{-\theta} v_{t},
\end{aligned}
$$

where $j_{0}$ and $g_{0}$ are respectively the steady state fraction (or average fraction over a whole business cycle) of non performing loans and of charged-off loans per period, $y_{t} / y$ represents the output gap ( $y$ is therefore the steady state output and $y_{t}$ the current output), $\theta>0$ and $\omega>0$ are the elasticities with respect to the output gap, and $z_{t}$ and $v_{t}$ represent shocks with mean one and standard deviation $\sigma_{z}$ and $\sigma_{v}{ }^{13}$. The output gap affects the financial situation of firms and households and therefore negatively affects the fraction of non performing loans and of charged-off loans. The shocks $z_{t}$ and $v_{t}$ underline that non performing loans and charged-off loans are not fully predictable even if the output gap is known. In addition, we do not assume that non performing loans and charged-off loans depend on the interest rate charged by the bank. The model does not focus on problems of moral hazard or adverse selection in the loan market ${ }^{14}$.

Equation (3) states that the bank profit comes from the interest rate on loans. However, interest earnings accrued but not received on problem loans and on charged-off loans during the period are subtracted from earnings. The bank receives therefore interest only on the proportion $\left(1-\mathrm{J}\left(y_{t}\right)-\mathrm{G}\left(y_{t}\right)\right)$ of its loan portfolio. The fraction $(1-\delta)$ of chargedoff loans had been provisioned over prior periods and does not affect current earnings, whereas unanticipated charged-off loans $\left(\delta L_{i, t} \mathrm{G}\left(y_{t}\right)\right)$ are subtracted from earnings since

\footnotetext{
${ }^{13}$ These shocks will be specified during the calibration of the model.

${ }^{14}$ We can also note than we do not assume that charged-off loans depend explicitly on last period's nonperforming loans because some loans can directly move from the good loans category to the chargedoff loans category and also because the fraction of nonperforming loans which move into the charged-off loans category is not necessarily the same for each period.
} 
they represent recognized losses which had not been anticipated. The bank has to pay for debts $\left(r_{t}^{M} D_{i, t}\right)$. In addition, loan loss provisions $\left(L L P_{i, t}\right)$ are charged against earnings to account for expected losses covered during the current period ${ }^{15}$. We can therefore see from equation (3) that provisioning rules influence the bank's profit.

Profits are shared between retained earnings $\left(K_{i, t+1}-K_{i, t}\right)$ used to modify the level of equity and dividends paid out to shareholders $\left(\Delta_{i, t}\right)$

$$
\Pi_{i, t}=K_{i, t+1}-K_{i, t}+\Delta_{i, t}
$$

Negatives dividends operate as equity issuing, and retained earnings are used to comply with the risk-based capital requirement which can be written as

$$
K_{i, t+1} \geqslant k_{0} L_{i, t+1}
$$

where $k_{0}$ is the regulatory threshold (the tier 1 requirement is $4 \%$ in Basel I) and we assume a risk weight on loans of one. We assume for simplicity that this regulatory constraint (equation (7)) is always binding; banks hold the minimum regulatory capital required ${ }^{16}$. Equation (6) shows that the choice between dividends and retained earnings is intertemporal. The level of capital at the beginning of the period $K_{i, t}$ is considered as given and the level of retained earnings chosen by the bank gives the level of capital available for the next period $\left(K_{i, t+1}\right)$. The risk-based capital requirement is therefore written for period $t+1$.

\footnotetext{
${ }^{15}$ Our variable $L L P_{i, t}$ has three different specifications according to the provisioning system considered (see section 2.2).

${ }^{16}$ This simplification allows us to focus on bank provisioning behavior. However, it could also be interesting in a further developement to examine the effects of the capital requirement on the banks' lending behavior. For example, Furfine (2001) considers in his model the cost of equity issuing and the cost related to a binding capital constraint in order to specify how the bank sets its equities.
} 


\subsection{Provisioning rules}

Provisioning rules are defined by the banking regulator. These rules can be backwardlooking, i.e. based on current non performing loans, or forward-looking, i.e. specified in order to smooth provisions made by the bank over a whole business cycle. In addition, if the bank believes that not enough loan loss provisions have been done according to regulatory requirements, the bank can hold a capital buffer.

We consider three specifications of the model according to provisioning rules and practices : a strict backward-looking provisioning system, a forward-looking provisioning system and a capital buffer system ${ }^{17}$.

\subsubsection{The strict backward-looking provisioning system}

The first provisioning system is a strict backward-looking provisioning system in which the bank strictly implements the backward-looking provisioning rules. The analysis of the bank's lending behavior in such a system will allow us to highlight the role of loan loss provisions in the pro-cyclical variation in loan market conditions. We therefore assume that the bank uses the accounting profit in its optimizing behavior and does not try to offset the weaknesses of the backward-looking accounting rules to determine the economic profit.

In a backward-looking provisioning system, loan loss provisions are driven by non performing loans. Loan loss reserves fit therefore identified problem loans rather than

\footnotetext{
${ }^{17} \mathrm{~A}$ forward-looking provisioning system is based on the way that banks set loan loss provisions (Fernandez de Lis et al. (2001), Jiménez and Saurina (2006)). We therefore focus on loan loss provisions rather than on loan loss reserves. In addition, we do not need to specify loan loss reserves to solve the model since they are invested in a safe asset. But by definition, variations in loan loss reserves are equal to loan loss provisions plus unanticipated charged-off loans (subtracted from earnings) minus charged-off loans (Walter, 1991). This implies that loan loss provisions are equal to anticipated charged-off loans at the steady state.
} 
expected loan losses ${ }^{18}$. Loan loss provisions are defined as following

$$
L L P_{i, t}=\mathrm{H}^{\mathrm{B}}\left(L_{i, t}, y_{t}\right)=h_{0} L_{i, t} \mathrm{~J}\left(y_{t}\right)
$$

where $L_{i, t}$ reprents the loans, $y_{t}$ is the current output, $h_{0}$ is the steady state fraction (or average fraction over a whole business cycle) of non performing loans $\left(L_{i, t} \mathrm{~J}\left(y_{t}\right)\right)$ which are covered by loan loss provisions during a period.

This specification ensures a counter-cyclical evolution of loan loss provisions which is the main stylized fact in a backward-looking provisioning system (see Clerc et al., 2001; Arpa et al., 2001; Fernandez de Lis et al., 2001 and Pain, 2003). Identified problem loans underestimate expected loan losses during an economic expansion and the bank has to make numerous loan loss provisions during the downturn. This system has therefore a pro-cyclical effect on bank profits.

\subsubsection{The forward-looking provisioning system}

In the forward-looking provisioning system, the accounting rules require that the bank make loan loss provisions related both to past due payments and to expected losses. Total loan loss provisions are therefore smoothed over time and loan loss reserves fit expected losses of the loan portfolio. Loan loss provisions in the forward-looking provisioning system are defined as follow

$$
L L P_{i, t}=\mathrm{H}^{\mathrm{F}}\left(L_{i, t}\right)=h_{0} L_{i, t} j_{0},
$$

\footnotetext{
${ }^{18} \mathrm{An}$ expected loss arises from the moment a loan is granted. Consequently, a future loss can be expected on a good loan. In addition, the bank can estimate its expected losses over a whole business cycle and deduce a constant expected losses per period.
} 
where $\mathrm{H}^{\mathrm{F}}\left(L_{i, t}\right)$ represents total loan loss provisions ${ }^{19}$. Loan loss provisions are smoothed around the steady state expected loss per period $\left(h_{0} L_{i, t} j_{0}\right)$. The counter-cyclicality of non performing loans related to the business cycle is not relevant anymore to determine loan loss provisions. As a result, economic profit and accounting profit are the same in such a system, as expected losses are perfectly taken into account by accounting rules.

\subsubsection{The capital buffer system}

In the capital buffer system, backward-looking provisioning rules are implemented but the bank takes into account the weaknesses of this accounting practice and tries to evaluate its economic profit. We assume that the bank builds a capital buffer $\left(K B_{t}\right)$ to cover the expected losses which are not covered by loan loss reserves ${ }^{20}$. The law of motion of the capital buffer is defined by

$$
K B_{i, t+1}=K B_{i, t}+\eta\left(\mathrm{H}^{\mathrm{F}}\left(L_{i, t}\right)-\mathrm{H}^{\mathrm{B}}\left(L_{i, t}, y_{t}\right)\right)
$$

The amount $\left(\mathrm{H}^{\mathrm{F}}\left(L_{i, t}\right)-\mathrm{H}^{\mathrm{B}}\left(L_{i, t}, y_{t}\right)\right)$ represents the difference between loan loss provisions in the forward-looking provisioning system and loan loss provisions in the backwardlooking provisioning system, i.e. provisions related to expected losses. A fraction $\eta \in[0 ; 1]$ is added to the capital buffer. For example, if problem loans are low $\left(\mathrm{H}^{\mathrm{F}}\left(L_{i, t}\right)>\right.$ $\left.\mathrm{H}^{\mathrm{B}}\left(L_{i, t}, y_{t}\right)\right)$, expected losses over period $t$ are understated in the backward-looking provi-

\footnotetext{
${ }^{19} \mathrm{H}^{\mathrm{F}}\left(L_{i, t}\right)$ reprents the sum of the two components of loan loss provisions, one related to past due payments and the other one related to expected losses. The latter component is therefore equal to $h_{0} L_{i, t} j_{0}\left(1-\left(y_{t} / y\right)^{-\omega} z_{t}\right)$. As a result, provisions in the forward-looking system do not explicitly depend on statistical prediction of non performing loans at period $t+1$. Rules are specified in order to smooth provisions made by the bank over a whole business cycle.

${ }^{20}$ Banks hold more prudential capital than that required by regulators, with a total capital buffers (Tier 1 plus Tier 2) on average across the EU15 of 2.93 per cent over the period 1997-2004 (Jokipii and Milne, 2006). Several reasons have been put forward to explain why banks hold excess capital (Jokipii and Milne, 2006). One of these explanations is that capital buffers can be used to cover expected future losses. In the model we do not make the distinction between Tier 1 capital and general provisions (which are included in Tier 2 capital). They are considered as equivalent in the capital buffer hold by the bank.
} 
sioning system and then the bank increases the capital buffer by $\eta\left(\mathrm{H}^{\mathrm{F}}\left(L_{i, t}\right)-\mathrm{H}^{\mathrm{B}}\left(L_{i, t}, y_{t}\right)\right)$ to obtain a better estimate of its economic profit $^{21}$. The capital buffer is added to standard equity $\left(K_{i, t}\right)$. We define therefore total capital $\left(T K_{i, t}\right)$ as

$$
T K_{i, t}=K_{i, t}+K B_{i, t}
$$

Then, the bank balance sheet becomes

$$
L_{i, t}+S_{i, t}-L L R_{i, t}=D_{i, t}+T K_{i, t}
$$

We assume that the capital buffer is invested in safe assets $\left(S_{i, t}\right)$ so that

$$
S_{i, t}=L L R_{i, t}+T K_{i, t}
$$

The bank's flow budget constraint is given by

$$
T K_{i, t+1}-T K_{i, t}+\Delta_{i, t}=r_{i, t}^{L} L_{i, t}\left(1-\mathrm{J}\left(y_{t}\right)-\mathrm{G}\left(y_{t}\right)\right)+r_{t}^{M} S_{i, t}-r_{t}^{M} D_{i, t}-L L P_{i, t}-\delta L_{i, t} \mathrm{G}\left(y_{t}\right) .
$$

\subsection{Loan demand}

We assumed that the representative bank $i$ operates in a monopolistic competition market. Banks offer differentiated loans and then each bank faces a specific demand for its type of loans. Based on Henzel et al. (2007) and Carletti et al. (2007), we define this

\footnotetext{
${ }^{21}$ The parameter $\eta$ is exogenous in the model. We do not specify the bank's incentive to build up a capital buffer. The capital buffer system is simply considered as an alternative to the forward-looking provisioning system.
} 
specific loan demand as

$$
L_{i, t}=\left(\frac{r_{i, t}^{L}}{r_{t}^{L}}\right)^{-\zeta} \mu L_{t}
$$

where $L_{t}$ is the aggregated demand for loans, $r_{t}^{L}$ is the average interest rate on loans, $\zeta$ is the elasticity of $L_{i, t}$ with respect to the interest rate on loans and $\mu$ is the bank market share (with $\mu=1 / N$ ). The parameter $\zeta$ represents therefore an inverse measure of the bank monopolistic power.

\section{The bank maximization behavior}

We assume that the bank maximizes the present discounted value of future dividends. The bank's maximization problem consists of choosing the interest on loans $\left(r_{i, t}^{L}\right)$. In the backward-looking provisioning system, the maximization problem is written as

$$
\max _{r_{i, t}^{L}} \mathrm{E}_{t} \sum_{j=0}^{\infty} \beta^{t+j} \Delta_{t+j}
$$

where

$$
\Delta_{t}=r_{i, t}^{L} L_{i, t}\left(1-\mathrm{J}\left(y_{t}\right)-\mathrm{G}\left(y_{t}\right)\right)-r_{t}^{M} D_{i, t}-L L P_{i, t}-\delta L_{i, t} \mathrm{G}\left(y_{t}\right)+K_{i, t}-K_{i, t+1}
$$

subject to equations (1), (2), (4), (5), (7), (8), and (15), and where $\beta$ is a standard discount factor ${ }^{22}$. In the forward-looking provisioning system, equation (8) is replaced with equation (9). In the capital buffer system, the bank maximization problem is the same than in the backward-looking provisioning system except that: $(i)$ equations $(10)$, (11) are added as constraints; (ii) equations (1) and (2) are replaced with equations (12)

\footnotetext{
${ }^{22}$ We assume that the discount factor is constant and does not depend on the cost of equity.
} 
and (13); (iii) dividends are given by equation (14).

\subsection{Optimal interest rate on loans}

The first order condition (FOC) gives the optimal interest rate on loans. We obtain in the backward-looking provisioning system (details are available upon request)

$$
r_{i, t}^{L}\left(1-\mathrm{J}\left(y_{t}\right)-\mathrm{G}\left(y_{t}\right)\right)=\frac{\zeta}{\zeta-1}\left\{r_{t}^{M}+h_{0} \mathrm{~J}\left(y_{t}\right)+\delta \mathrm{G}\left(y_{t}\right)+\left(k_{0} / \beta-k_{0}\right)\right\} .
$$

As the bank earns interest only on a fraction of their loans $\left(1-J\left(y_{t}\right)-\mathrm{G}\left(y_{t}\right)\right)$, the lefthand side of equation (18) represents the marginal return on loans. The right-hand side of equation (18) shows that several factors influence the bank when setting the loan interest rate. More precisely, the bank applies a mark-up $(\zeta /(\zeta-1))$ on the marginal cost of its lending activity.

There are four components in the marginal cost of the bank's lending activity : the cost of debt $\left(r_{t}^{M}\right)$, the provisioning cost $\left(h_{0} \mathrm{~J}\left(y_{t}\right)\right)$, the unanticipated charge-offs cost $\left(\delta \mathrm{G}\left(y_{t}\right)\right)$ and the cost related to the capital requirement $\left(\left(k_{0} / \beta-k_{0}\right)\right)$. Anticipated recognized losses had been provisioned over prior periods and do not affect the current profit. As a result, provisioning rules (i.e. the rules according to which losses are anticipated) matter in the optimal decision concerning the loan interest rate. In the strict backward-looking system, loan loss provisions depend mainly on problem loans and then the provisioning cost is negatively affected by the business cycle.

This effect of provisioning rules on the loan rate is different in the forward-looking provisioning system. The FOC is given by

$$
r_{i, t}^{L}\left(1-\mathrm{J}\left(y_{t}\right)-\mathrm{G}\left(y_{t}\right)\right)=\frac{\zeta}{\zeta-1}\left\{r_{t}^{M}+h_{0} j_{0}+\delta \mathrm{G}\left(y_{t}\right)+\left(k_{0} / \beta-k_{0}\right)\right\}
$$


Provisions related to expected losses offset the counter-cyclical evolution of provisions related to past due payments, so that loan loss provisions are no more affected by the counter-cyclical evolutions of problem loans. As a result, the marginal provisioning cost is given by $h_{0} j_{0}$.

In the capital buffer system, the bank applies backward-looking provisioning rules and creates a capital buffer to cover the expected loan losses which are not covered by loan loss reserves. The optimal decision regarding the interest rate on loans is given by

$$
r_{i, t}^{L}\left(1-\mathrm{J}\left(y_{t}\right)-\mathrm{G}\left(y_{t}\right)\right)=\frac{\zeta}{\zeta-1}\left\{r_{t}^{M}+h_{0}\left(\eta j_{0}+(1-\eta) \mathrm{J}\left(y_{t}\right)\right)+\delta \mathrm{G}\left(y_{t}\right)+\left(k_{0} / \beta-k_{0}\right)\right\}
$$

The differences between equations (19) and (20) show that the bank's behavior is identical in the capital buffer system and the forward-looking provisioning system only if $\eta=1$. Under this condition, the expected losses not covered by loan loss reserves are fully covered by the capital buffer. However, a high capital buffer requires that the bank uses retained earnings to increase its capitalization instead of increasing dividends during economic upswings. Shareholders may not appreciate such a strategy and may demand higher dividends (and then $\eta<1$ ). Banks may therefore not be able to completely offset the counter-cyclical evolution of loan loss provisions by building a capital buffer. The forward-looking provisioning system presents the advantage to require banks to also make provisions related to expected losses that smooth the evolution of total loan loss provisions. 


\subsection{Business cycle and loan market}

We can see with equations (18), (19) and (20) that the interest rate on loans is the same in the three provisioning systems when considering the steady state. It is given by ${ }^{23}$

$$
r^{L}\left(1-j_{0}-g_{0}\right)=\frac{\zeta}{\zeta-1}\left\{r^{M}+h_{0} j_{0}+\delta g_{0}+\left(k_{0} / \beta-k_{0}\right)\right\}
$$

where $r^{L}$ and $r^{M}$ represent respectively the steady state value of the loan interest rate and of the interest rate on debts.

However, the short term dynamics in the loan market are different for the three provisioning systems. These dynamics can be appreciated by log-linearizing the first order condition on the interest rate on loans (equations (18), (19) and (20)). We also introduce the aggregate loan demand. Based on the work of Calza et al. (2006), the aggregate loan demand is as following ${ }^{24}$

$$
\hat{L}_{t}=\phi_{y} \hat{y}_{t}-\phi_{r^{L}}\left(\hat{r}_{t}^{L}-\mathrm{E}_{t}\left\{\hat{\pi}_{t+1}\right\}\right)
$$

where $\pi_{t}$ is the inflation rate. The aggregate loan demand increases when output increases, and decreases when the real loan rate increases.

In the backward-looking provisioning system, the log-linearization of equation (18) is given by (details are available upon request)

$$
\varphi_{0} \hat{r}_{t}^{L}=\varphi_{1} \hat{r}_{t}^{M}+\varphi_{2} \hat{z}_{t}+\varphi_{3} \hat{v}_{t}-\varphi_{4} \hat{y}_{t}
$$

\footnotetext{
${ }^{23}$ We consider the symetric equilibrium to determine the steady state $\left(r_{i, t}^{L}=r_{t}^{L}=r^{L}\right)$.

${ }^{24}$ The variable $\hat{X}_{t}$ denotes the percentage (logarithmic) deviations of the variable $X_{t}$ from its steady state value $X$.
} 
where $\varphi_{0} \equiv r^{L}\left(1-j_{0}-g_{0}\right), \varphi_{1} \equiv Z r^{M}, \varphi_{2} \equiv r^{L} j_{0}+Z h_{0} j_{0}, \varphi_{3} \equiv r^{L} g_{0}+Z \delta g_{0}, \varphi_{4} \equiv \omega \varphi_{2}+\theta \varphi_{3}$ and $Z \equiv \zeta /(\zeta-1)$.

The loan market dynamics depend on several factors. First, deviations of the loan rate $\left(\hat{r}_{t}^{L}\right)$ around its steady state depend on deviations of the interest rate on debt $\left(\hat{r}_{t}^{M}\right)$. Variations in financing costs are therefore passed on to the loan rate and lead to changes in loans $\left(\hat{L}_{t}\right)$ as we can see from equation $(22)$.

Second, shocks on problem loans $\left(\hat{z}_{t}\right)$ and on charged-off loans $\left(\hat{v}_{t}\right)$ positively affect the loan rate $\hat{r}_{t}^{L}$. We have an increase in credit risk in case of positive shocks, which leads to an increase in the loan rate and then to a decrease in loans. The effect of a charged-off loans shock on $\hat{r}_{t}^{L}$ is measured by the parameter $\varphi_{3}$. This parameter is made up of two components and suggests that an increase in the fraction of charged-off loans impacts on $\hat{r}_{t}^{L}$ because the bank faces $(i)$ a decrease in interest earnings $\left(r^{L} g_{0}\right)$ and $(i i)$ an unanticipated loss $\left(Z \delta g_{0}\right)$. Similarly, the effect of a non performing loans shock is measured by the parameter $\varphi_{2}$. An increase in the fraction of non performing loans leads to both a decrease in interest earnings $\left(r^{L} j_{0}\right)$ and to an increase of provisions $\left(Z h_{0} j_{0}\right)$, as suggested by the two components of the parameter $\varphi_{2}$.

Third, the business cycle $\left(\hat{y}_{t}\right)$ negatively affects the loan rate $\hat{r}_{t}^{L}$. This effect is measured by the parameter $\varphi_{4} \equiv \omega \varphi_{2}+\theta \varphi_{3}$. The business cycle affects the bank's behavior through its impact on the levels of non performing loans and of charged-off loans. An economic downturn implies an increase in problem loans and charged-off loans, leading to an increase in the loan rate. This reinforces the direct effect of the business cycle on loans, measured by the parameter $\phi_{y}$ in equation (22).

Equations (22) and (23) show therefore that the provisioning system matters in the loan market dynamics. Provisions are driven by problem loans in a backward-looking 
provisioning system. These provisioning rules amplify the effects of the business cycle $\left(\hat{y}_{t}\right)$ and of a non performing loans shock $\left(\hat{z}_{t}\right)$ on the loan market. This amplification effect is measured by $Z h_{0} j_{0}$ in the parameter $\varphi_{2}$.

\section{Proposition 1:}

A backward-looking provisioning system amplifies the effect of the business cycle on the loan market. The magnitude of this effect depends on the impact of the business cycle on loan loss provisions.

This magnifying effect of loan loss provisions on the loan market is no more relevant in a forward-looking provisioning system where loan loss provisions do not only depend on problem loans. The log-linearization of the FOC on the loan interest rate (equation (19)) is given by

$$
\varphi_{0} \hat{r}_{t}^{L}=\varphi_{1} \hat{r}_{t}^{M}+\varphi_{2}^{\prime} \hat{z}_{t}+\varphi_{3} \hat{v}_{t}-\varphi_{4}^{\prime} \hat{y}_{t}
$$

where $\varphi_{2}^{\prime} \equiv r^{L} j_{0}$ and $\varphi_{4}^{\prime} \equiv \omega \varphi_{2}^{\prime}+\theta \varphi_{3}$.

The effect of a non performing loans shock is smaller in the forward-looking provisioning system $\left(\varphi_{2}^{\prime}<\varphi_{2}\right)$. The effect of the business cycle is also smaller $\left(\varphi_{4}^{\prime}<\varphi_{4}\right)$. The deviations of the loan rate as well as the fluctuations in the loan market are therefore less important in a forward-looking provisioning system where provisions related to past due payments do not longer affect the bank's behavior since their variations are offset by provisionsmade to cover expected losses.

\section{Proposition 2:}

The provisioning rules do not amplify the effect of the business cycle on the loan market in a forward-looking provisioning system.

The third provisioning system that we considered is the capital buffer system. The 
log-linearized FOC on the loan rate (equation (20)) is given by

$$
\varphi_{0} \hat{r}_{t}^{L}=\varphi_{1} \hat{r}_{t}^{M}+\varphi_{2}^{\prime \prime} \hat{z}_{t}+\varphi_{3} \hat{v}_{t}-\varphi_{4}^{\prime \prime} \hat{y}_{t}
$$

where $\varphi_{2}^{\prime \prime} \equiv r^{L} j_{0}+Z(1-\eta) h_{0} j_{0}$ and $\varphi_{4}^{\prime \prime} \equiv \omega \varphi_{2}^{\prime \prime}+\theta \varphi_{3}$.

If $\eta$ is equal to 1 , the capital buffer and loan loss reserves are mixed to fully cover expected losses. In this case, the behavior of the bank is the same as in the forwardlooking provisioning system $\left(\varphi_{2}^{\prime \prime}=\varphi_{2}^{\prime}\right.$ and $\left.\varphi_{4}^{\prime \prime}=\varphi_{4}^{\prime}\right)$ and provisioning rules do not amplify the effect of the business cycle ${ }^{25}$. However, the constraint $\eta=1$ requires the bank to accumulate a capital buffer during the economic expansion which will be used during the downturn.

\section{Proposition 3:}

The use of a capital buffer to cover the expected losses offsets the effect of the business cycle on provisions; however, this might imply a high fluctuation in the capital of the bank.

\section{Concluding remarks}

Our model shows that accounting rules on loan loss provisions matter to explain loan market fluctuations. We find that a backward-looking provisioning system amplifies the pro-cyclicality of bank lending. Such an effect is removed in a forward-looking provisioning system where statistical provisions smooth total loan loss provisions over the business cycle. This effect can also be removed with a capital buffer system, but this solution might imply large variations in banks' equity. Our work therefore shows that

\footnotetext{
${ }^{25}$ If $\eta=0$, we also note that $\varphi_{2}^{\prime \prime}=\varphi_{2}$ and $\varphi_{4}^{\prime \prime}=\varphi_{4}$.
} 
the capital requirement is not the only institutional constraint which may amplify the cyclicality of lending. Accounting rules on loan loss provisions are also a decisive factor to explain the pro-cyclicality of banks' behavior. A strict backward-looking provisioning system contributes to amplify the cyclicality of bank lending and a capital buffer cannot easily remove this effect. In Europe, the provisioning system is backward-looking (excluding Spain) but banks do not implement these accounting rules strictly. Consequently, for practical purposes, European banks behave as if in a capital buffer system in which banks can try to offset weaknesses of backward-looking provisioning rules. Clerc et al. (2001) highlight that such a system leads to a procyclical evolution of the ratio of loan loss provisions to total loans. It means that European banks do not succeed in offsetting weaknesses of backward-looking provisioning rules by covering expected losses with equity or discretionary loan loss provisions.

The conclusions from this paper support the recent call of the Basel Committee for the implementation of a forward-looking provisioning system to address procyclicality. More precisely, the reform programme developed by the Basel Committee and referred as "Basel III" stresses the importance of implementing a capital buffer system and a forward-looking provisioning system as prudential measures to mitigate procyclicality in the banking sector (Basel Committee on Banking Supervision, 2010). But such a reform requires a change of accounting standards towards an expected loss approach. In this regard, the Committee is working closely with the International Accounting Standards Board (IASB) to reform the Fair Value Accounting system based on IAS 39. The objective is to reform "the accounting model for provisioning to allow early identification and recognition of losses by incorporating a broader ranger of available credit information than presently included in the incurred loss model" (Basel Committee on Banking Supervision, 2009). 
The implementation of a such model that allows earlier recognition of credit losses will build up the level of provisions at an earlier point in time and will decrease the cyclicality of lending; this could help financial institutions to cope better with potential future crises.

\section{References}

Ahmed, A., Takeda, C., Thomas, S. (1999). "Bank loan loss provisions: a re-examination of capital management, earnings management and signaling effects". Journal of Accounting and Economics, 28, 1-26.

Arpa, M., Giulini, I., Ittner, A., Pauer, F. (2001). "The influence of macroeconomic developments on Austrian banks: implications for banking supervision". BIS Papers, 1, 91-116.

Asea, P., Blomberg, B. (1998). "Lending cycles". Journal of Econometrics, 83, 89-128.

Basel Committee on Banking Supervision, 2010. "The Basel Committee's response to the financial crisis: Report to the G20". Bank of International Settelments.

Basel Committee on Banking Supervision, 2009. "Guiding principles for the replacement of IAS 39". Bank of International Settelments.

Berger, A., Udell, G. (2004). "The institutional memory hypothesis and the procyclicality of bank lending behavior". Journal of Financial Intermediation, 13, 458-495.

Bikker, J., Metzemakers, P. (2005). "Bank provisioning behavior and procyclicality". Journal of International Financial Markets, Institutions and Money, 15, 141-157.

Bikker, J. (2004). "Cyclical patterns in profits, provisioning and lending of banks." In Competition and efficiency in a unified European banking market, 241-273.Edward Elgar.

Borio, C., Furfine, C., Lowe, P. (2001). "Procyclicality of the financial system and financial stability: issues and policy options". BIS Papers, 1, 1-57.

Bouvatier, V., Lepetit, L. (2010). "Effects of loan loss provisions on growth in bank lending : some international comparisons". Mimeo.

Bouvatier, V., Lepetit, L. (2008). "Banks' procyclicality behavior: does provisioning matter ?", Journal of International Financial Markets, Institutions \& Money, 18, 513528.

Calza, A., Manrique, M., Sousa, J. (2006). "Credit in the euro area: An empirical investigation using aggregate data". The Quarterly Review of Economics and Finance, 46, 211-226.

Carletti, E., Hartmann, P., Spagnolo, G. (2007). "Bank mergers, competition and liquidity". Journal of Money, Credit and Banking, 39, 1067-1105. 
Cavallo, M., Majnoni, G. (2001). "Do banks provision for bad loans in good time? Empirical evidence and policy implications". World Bank, Working Paper \#2619.

Clerc, L., Drumetz, F., Jaudoin, O. (2001). "To what extent are prudential and accounting arrangements pro- or countercyclical with respect to overall financial conditions?" BIS Papers, 1, 197-210.

Fernandez de Lis, S., Martinez Pagès, J., Saurina, J. (2001). "Credit growth, problem loans and credit risk provisioning in Spain". BIS Papers, 1, 331-353

Furfine, C. (2001). "Bank portfolio allocation: the impact of capital requirements, regulatory monitoring and economic conditions". Journal of Financial Services Research, 20, 33-56.

Guttentag, J., Herring, R. (1986). "Disaster myopia in international banking". Princeton University, Essays in International Finance \#164.

Henzel, S., Hülsewig, O., Mayer, E., Wollmershäuser, T. (2007). "The price puzzle revisited: can the cost channel explain a rise in inflation after a monetary policy shock?" CESifo, Working Paper \#2039.

Jiménez, G., Saurina, J. (2006). "Credit cycles, credit risk, and prudential regulation". International Journal of Central Banking, 2, 65-98.

Jokipii, T., Milne, A. (2006). "The cyclical behaviour of European bank capital buffers". Bank of Finland, Discussion Paper \#17/2006.

Laeven, L., Majnoni, G. (2003). "Loan Loss Provisioning and Economic Slowdowns: Too Much, Too Late?" Journal of Financial Intermediation, 12, 178-197.

Lown, C., Morgan, D. (2006). "The credit cycle and the business cycle: new findings using the loan officer opinion survey". Journal of Money, Credit and Banking, 38, 1575-1598.

Mann, F., Michael, I. (2002). "Dynamic provisioning: issues and application". Bank of England, Financial Stability Review, 12, 128-136.

Pain, D. (2003). "The provisioning experience of the major UK banks: A small panel investigation". Bank of England, Working Paper.\#177.

Perez, D., Salas-Fumas, V., Saurina, J. (2008). "Earnings and Capital Management in Alternative Loan Loss Provision Regulatory Regimes". European Accounting Review, 17, 423-445.

Rajan, R. (1994). "Why bank credit policies fluctuate: A theory and some evidence". The Quaterly Journal of Economics, 109, 399-441.

Reinhart, C., Rogoff, K. (2009). "This time is different, eight centuries of financial folly". Ed. Princeton University Press.

Van den Heuvel, S. (2002). "The bank capital channel of monetary policy". Unpublished manuscript, University of Pennsylvania.

Walter, J. (1991). "Loan loss reserves". Federal Reserve Bank of Richemond, Economic Review, July/August, 20-30. 
Zicchino, L. (2006). "A model of bank capital, lending and the macroeconomy: Basel I versus Basel II". Manchester School, Supplement 2006, 74, 50-77. 